\title{
Properties of Escherichia coli Grown in vivo Using a Chamber Implant System
}

\author{
By THERESA M. FINN*, JOHN P. ARBUTHNOTT AND GORDON \\ DOUGAN
}

Department of Microbiology, Moyne Institute, Trinity College, Dublin 2, Ireland

(Received 14 January 1982; revised 11 May 1982)

\begin{abstract}
Strains of Escherichia coli were examined for their ability to grow in diffusion chambers implanted into the peritoneal cavities of mice and rabbits. In rabbit chambers $E$. coli $\mathrm{K} 12$ strains grew poorly, whereas isogenic strains harbouring ColV plasmids and wild-type isolates from extra-intestinal infections grew well. The difference was much less marked with strains grown in mouse chambers. Differences in sensitivity to the bactericidal action of human or rabbit serum were found in some cases between organisms of the same strain grown in vivo or in vitro. Host immunoglobulins were bound to the surface of all in vivo bacteria. Comparison of the polypeptide composition of bacterial cell envelope preparations on SDS-PAGE gels revealed differences between in vivo and in vitro grown $E$. coli. Thus $E$. coli growing in vivo may possess properties significantly different from the same organisms growing on laboratory medium.
\end{abstract}

\section{INTRODUCTION}

Certain strains of Escherichia coli can cause extra-intestinal infections especially in children and domestic animals. A number of determinants have been implicated as virulence factors in these invasive strains including encapsulation, lipopolysaccharide production and possession of ColV plasmids (Smith, 1974, 1977; Smith \& Huggins, 1980). The K1 polysaccharide is often associated with $E$. coli strains from neonatal meningitis (Robbins et al., 1974) and particular O lipopolysaccharide serotypes are also associated with these strains. ColV plasmids encode a number of virulence factors including iron chelating systems (Williams \& Warner, 1980) and serum resistance determinants (Binns et al., 1979), which can increase the virulence of $E$. coli strains harbouring these plasmids in animal model systems (Smith, 1974). However, it is likely that the pathogenesis of invasive infections is multifactorial involving combinations of virulence factors.

Few reports have dealt with the properties of $E$. coli cultured in vivo (Roantree \& Collis, 1960) and most characterization of virulence determinants has been carried out using $E$. coli grown on laboratory media. The conditions under which bacteria are cultivated affects their metabolic activity and surface composition (Smith, 1977) and some virulence factors may not be expressed when the organisms are cultivated outside the host (Penn et al., 1976). Conversely, potential virulence factors identified in vitro may play little or no role in the pathogenesis of disease. A number of reports have described systems for the cultivation of bacteria in vivo (Arko, 1972; Gladstone \& Glencross, 1960, Houser \& Berry, 1961). Recently a simple system was developed in this laboratory for growing small quantities of bacteria in vivo using a chamber implantation system (Day et al., 1980).

This paper describes the properties of a number of $E$. coli strains grown in chambers implanted into the peritoneal cavities of rabbits and mice. Bacteria isolated after periods of growth in vivo were examined using a number of techniques. The results were compared to those obtained using bacteria grown on normal laboratory media.

Abbreviations: NHS, normal human serum; NMS, normal mouse serum; NRS, normal rabbit serum; PBS, phosphate-buffered saline. 


\section{METHODS}

Animals. Male Balb/C mice, 8-10 weeks old, and male New Zealand rabbits weighing 3-3.5 kg were used. They were maintained under normal laboratory conditions in standard cages with unrestricted access to food and water.

Bacterial strains and growth conditions. The characteristics and sources of the $E$. coli strains and plasmids used in this study are listed in Table 1 . In vitro grown bacteria were cultured on $1.2 \%(\mathrm{w} / \mathrm{v})$ New Zealand nutrient agar $(\mathrm{BDH}) \mathrm{pH} 7.4$ containing $0.5 \%(\mathrm{w} / \mathrm{v})$ Lab Lemco (Oxoid), $0.5 \%(\mathrm{w} / \mathrm{v}) \mathrm{NaCl}$ and $1 \%(\mathrm{w} / \mathrm{v})$ peptone (Oxoid), or in nutrient broth (composition as for nutrient agar) at $37^{\circ} \mathrm{C}$ with shaking (Gallenkamp orbital shaking platform, 150 r.p.m.). For inoculation into chambers, single colonies picked from nutrient agar cultures were grown overnight at $37^{\circ} \mathrm{C}$ in $2 \mathrm{ml}$ broth and diluted in physiological saline to give a final concentration of $10^{4}$ viable organisms $\mathrm{ml}^{-1}$. Suspensions were maintained on ice prior to the inoculation of the chambers; $0.1 \mathrm{ml}$ of suspension was introduced into each chamber, which was then sealed. Chambers were constructed as described by Day et al. (1980). Chambers for implantation into mice (mouse chambers) were made from syringe barrels ( $1 \mathrm{ml}$ capacity) (Becton $\&$ Dickinson, Dublin) and were $7 \times 10 \mathrm{~mm}$ in dimension. The ends were covered with $0.22 \mu \mathrm{m}$ pore filters (Millipore). Chambers for implantation into rabbits (rabbit chambers) were constructed from $10 \mathrm{ml}$ syringe barrels and measured $16 \times 40 \mathrm{~mm}$.

Two chambers were implanted intraperitoneally into each mouse. To recover the bacteria, chambers were removed from mice killed by cervical dislocation; the chambers were rinsed with sterile distilled water and the contents were removed through the sides using a hypodermic syringe. The contents were then transferred to capped microtubes that were kept on ice. A viable count was obtained by diluting $20 \mu \mathrm{l}$ samples and plating on to nutrient agar plates. The remaining bacteria were either kept on ice for immediate use or harvested by centrifugation in a microfuge $(9980 \mathrm{~g}$ for $1 \mathrm{~min})$. After centrifugation, supernatants were stored at $-20^{\circ} \mathrm{C}$ and the bacterial pellet, after washing once in saline, was resuspended in $40 \%(\mathrm{v} / \mathrm{v})$ glycerol and stored at $-20^{\circ} \mathrm{C}$.

For growth in rabbits, five chambers each containing $5.5 \mathrm{ml}$ of bacterial suspension $\left(10^{4}\right.$ organisms $\left.\mathrm{ml}^{-1}\right)$ were placed in the peritoneal cavity of each rabbit. Chamber contents were collected after $7 \mathrm{~d}$, and after determining the viable count, organisms harvested by centrifugation $\left(10000 \mathrm{~g}, 4^{\circ} \mathrm{C}\right)$. The supernatant was removed and stored at $-20{ }^{\circ} \mathrm{C}$ and organisms were used immediately without washing, stored at $-20^{\circ} \mathrm{C}$ in $40 \%(\mathrm{v} / \mathrm{v})$ glycerol, or were drained and stored at $-70^{\circ} \mathrm{C}$ before preparing envelopes. Anti-meningococcal group B specific antiserum (Wellcome) was used to detect $\mathrm{K} 1$ capsular material.

Growth in vivo. Each strain was examined for ability to survive and multiply in chambers implanted into rabbits and mice. Groups of twelve mice were implanted with duplicate chambers containing suspensions of one of the $E$. coli strains. Pairs of mice were then sacrificed each day over a $6 \mathrm{~d}$ period and a viable count was obtained for each chamber by plating dilutions on to nutrient agar. Each strain was tested in at least two groups of 12 mice.

Serum resistance tests. Resistance to the bactericidal activity of serum was tested using a modification of the viable count procedure described by Moll et al. (1980). In vitro grown bacteria harvested by centrifugation after overnight growth in broth were washed once in phosphate-buffered saline (PBS) pH 7.4 and diluted in PBS to obtain a final concentration of $10^{6}$ cells $\mathrm{ml}^{-1}$. In vivo grown bacteria were harvested and diluted in the same way. Diluted samples $(25 \mu \mathrm{l})$ were mixed with $100 \mu \mathrm{l}$ of undiluted serum and incubated at $37^{\circ} \mathrm{C}$ for $2 \mathrm{~h}$. Viable counts were determined immediately after addition of serum and after $2 \mathrm{~h}$ incubation at $37^{\circ} \mathrm{C}$, by plating dilutions on to nutrient agar.

Table 1. Escherichia coli strains and plasmids used
Strain Genotype/phenotype
Relevant characteristics and plasmids
Source

\section{DU1000} trp his lys $\mathrm{Nal}^{\mathrm{R}}$

B188 $\mathrm{Nal}^{\mathrm{R}}$

$\begin{array}{cl}\text { W3110 } & \text { rpsL nalA } \\ \text { W3110 } & \text { As for W3110 } \\ \text { (ColV,I-K94) } & \\ \text { AN1937 } & \text { arg entA lac } \\ & \text { leu mtl proC } \\ & \text { rpsL supE thi } \\ \text { AN1937 } & \text { tonA trpE xyl } \\ \text { (ColV,H-247) } & \text { As for AN } 1937 \\ \text { A21 } & \text { prototroph }\end{array}$

Commonly used laboratory K12 E. coli strain

$\mathrm{O} 78: \mathrm{K} 80$; isolated from a calf bacteraemia due to infection with this strain

E. coli $\mathrm{K} 12$

E. coli K 12 harbouring ColV plasmid shown to increase resistance to the bactericidal action of serum

E. coli $\mathrm{K} 12$ defective in enterochelin production

AN1937 harbouring ColV plasmid encoding a plasmid-borne iron uptake system $07: \mathrm{K} 1$; isolated from a case of neonatal meningitis
Foster \& Willetts (1976)

Quakenbush \& Falkow (1979)

Williams \& Warner (1980)

Williams \& Warner (1980)

Williams \& Warner (1980)

Williams \& Warner (1980)

M. Achtman, Max-Planck Institute, Berlin, F.R.G. 
Bacteria were tested against normal human (NHS), rabbit (NRS) and mouse (NMS) serum. To obtain serum, blood was allowed to clot overnight at $4{ }^{\circ} \mathrm{C}$ and was then centrifuged at $2000 \mathrm{~g}$ for $5 \mathrm{~min}$; serum was stored at $-20{ }^{\circ} \mathrm{C}$ until required.

Washing of bacteria and preparation of cell envelopes. In vivo grown bacteria were prepared from the contents of two rabbit chambers and in vitro grown bacteria were prepared from an equivalent volume (11 ml), containing approximately the same number of bacteria, of an overnight culture in nutrient broth. The bacteria were harvested by centrifugation $\left(10000 \mathrm{~g}, 4{ }^{\circ} \mathrm{C}\right.$ for $\left.10 \mathrm{~min}\right)$ and the pellets were drained. The supernatant fluids were stored at $-20^{\circ} \mathrm{C}$. The bacteria were then washed three times with $2 \mathrm{ml}$ volumes of $0 \cdot 2 \mathrm{M}$-Tris $/ \mathrm{HCl}, \mathrm{pH} 8 \cdot 0$. The washes were separately concentrated by dialysis overnight against ammonium sulphate $\left(90 \%\right.$ saturation) at $4{ }^{\circ} \mathrm{C}$. The precipitated protein was harvested using a microfuge $(9980 \mathrm{~g}$ for $2 \mathrm{~min}$ ) and was resuspended in $50 \mu \mathrm{l} 0.05 \mathrm{M}$ Tris $/ \mathrm{HCl}, \mathrm{pH} 8.0$. Washed bacteria were resuspended in $1 \mathrm{ml} 0.2 \mathrm{M}-\mathrm{Tris} / \mathrm{HCl}, \mathrm{pH} 8.0$ at $4{ }^{\circ} \mathrm{C}$ and lysed according to the methods of Witholt et al., 1976. Resuspended bacteria were diluted with $1 \mathrm{ml} 0.2 \mathrm{M}-\mathrm{Tris} / \mathrm{HCl}, 1 \mathrm{M}$-sucrose, $0.005 \mathrm{M}$-EDTA pH 8.0 and lysozyme was added to a final concentration of $60 \mu \mathrm{g} \mathrm{ml}^{-1}$. This mixture was then diluted with an equal volume of cold distilled water and the bacteria were disrupted by sonication (MSE sonicator) using $5 \times 30$ s bursts with cooling on ice. Any remaining spheroplasts were lysed by adding $25 \mathrm{ml}, 0 \cdot 01 \mathrm{M}$-EDTA $\mathrm{pH} 8 \cdot 0$. The lysate was centrifuged at $5000 \mathrm{~g}$ to remove remaining whole cells. The supernatant was decanted into a second centrifuge tube and cell envelopes were harvested by centrifuging at $48000 \mathrm{~g}$ for $\mathrm{l} \mathrm{h}$. Envelopes were resuspended in $50 \mu \mathrm{l}$ of sample buffer, $0.0625 \mathrm{M}-\mathrm{Tris} / \mathrm{HCl}, \mathrm{pH} 6.8,3 \%(\mathrm{w} / \mathrm{v}) \mathrm{SDS}, 5 \%(\mathrm{v} / \mathrm{v})$ mercaptoethanol, $0.01 \%(\mathrm{w} / \mathrm{v})$ bromophenol blue and $10 \%(\mathrm{v} / \mathrm{v})$ glycerol, boiled for $3 \mathrm{~min}$ and stored at $4{ }^{\circ} \mathrm{C}$. SDS-PAGE was carried out in $12.5 \%(\mathrm{w} / \mathrm{v})$ gels by the method of Dougan \& Sherratt (1977). Equal volumes were loaded on each track; protein bands were stained by Coomassie blue R250.

Double diffusion tests. Buffer washes of in vivo (rabbit chambers) and in vitro grown bacteria were concentrated with ammonium sulphate ( $90 \%$ saturation). Trace amounts of ammonium sulphate were removed by dialysis against PBS and concentrates were tested against swine anti-rabbit immunoglobulins, (DAKO-Immunoglobulins, Copenhagen, Denmark) and swine anti-rabbit serum proteins (DAKO).

Electron microscopy. Bacteria were stained using the method of Weiss et al. (1979), which employs cationic ferritin to label the anionic surface components of glutaraldehyde-fixed cells. After staining, samples were encapsulated in $1.8 \%$ Noble agar, cut into small segments and fixed with $2 \%(\mathrm{w} / \mathrm{v})$ osmium tetroxide in $0.2 \mathrm{M}-$ potassium phosphate buffer $\mathrm{pH} 6.8$ for $1.5 \mathrm{~h}$ in a fume cupboard. Samples were dehydrated in acetone and embedded in Epon/Araldite. Thin sections were stained with $2 \%(\mathrm{w} / \mathrm{v})$ aqueous uranyl acetate and lead citrate before examination under a Hitachi $12 \mathrm{~A}$ transmission electron microscope at $75 \mathrm{kV}$.

\section{RESULTS}

Growth of $E$. coli strains in chambers implanted into mice and rabbits

When $E$. coli strains were examined for their ability to grow in mouse chambers it was found that all strains grew to some extent over the $6 \mathrm{~d}$ period (see Fig. 1 for examples). Strains B188,

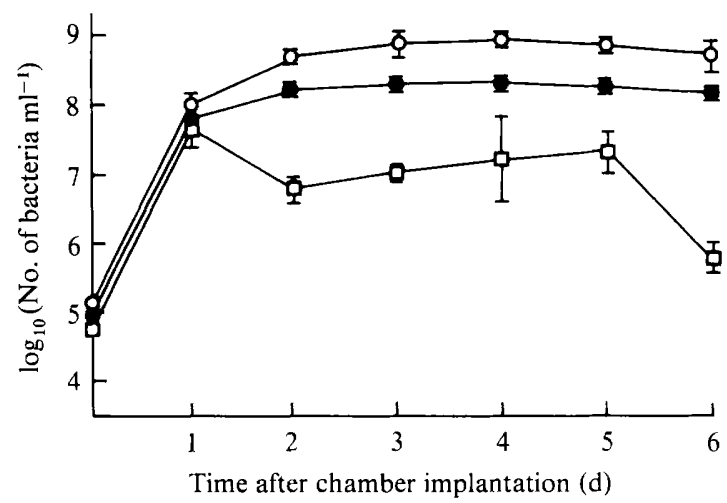

Fig. 1. Viable counts obtained when $E$. coli strains were grown in mouse chambers over a $6 \mathrm{~d}$ period. Each strain was grown in at least two groups of twelve mice and at each time point two mice were sacrificed and a viable count carried out on each chamber (bars denote S.E.). From $2 \mathrm{~d}$ onwards, viable counts were significantly different $(P=0.05$ as determined by Student's $t$ test $)$ for each strain at each sampling time. O, B188; O, AN1937(ColV-H247); $\square$, AN1937. 
$\mathrm{A} 21$ and W3110 (ColV, I-K94) grew to a density of greater than $10^{8}$ organisms ml-1 within $24 \mathrm{~h}$ and maintained a concentration as high as $10^{8}$ organisms $\mathrm{ml}^{-1}$ in a steady manner over the $6 \mathrm{~d}$ period. The K12 strains DU1000 and W3110 took $48 \mathrm{~h}$ to reach $10^{8}$ organisms $\mathrm{ml}^{-1}$ and fluctuated between $10^{7}$ and $10^{8}$ organisms $\mathrm{ml}^{-1}$ over $6 \mathrm{~d}$. AN1937, which is a $\mathrm{K} 12$ strain defective in enterochelin synthesis, grew as well as other strains over the first $24 \mathrm{~h}$ but remained at a lower viable count over the next $5 \mathrm{~d}$. This strain was tested in several groups of mice and showed great fluctuation in viable counts. It is noteworthy that on plating out this strain after $6 \mathrm{~d}$ of growth in vivo, up to $25 \%$ of the resultant colonies had a mucoid appearance. The mucoid colonies were shown to be variants of AN1937 since they failed to grow on medium containing $\alpha \alpha^{\prime}$-dipyridyl $\left(1.6 \times 10^{-4} \mathrm{M}\right)$, which inhibits the growth of the enterochelin-deficient strain AN1937. The mucoid morphology of these variants was found to be stable following subculture in vitro or in mouse chambers, although growth remained poor. When AN1937 harbouring ColV-H247, which encodes for an iron uptake system, was grown in mouse chambers, the organism grew well (Fig. 1) and reached similar levels to the wild-type strains. Striking differences were found with individual strains in their ability to survive and grow in rabbit chambers. The K12 strains DU1000, W3110 and AN1937 each grew poorly in these chambers and less than $10^{3}$ viable organisms $\mathrm{ml}^{-1}$ could be recovered after $7 \mathrm{~d}$ in vivo. In contrast, strains W3110(ColV, I-K94), AN1937 (ColV-H247), B188 and A21 grew to high density in rabbit chambers; up to $10^{9}$ organisms $\mathrm{ml}^{-1}$ were recovered after $7 \mathrm{~d}$ implantation. Thus, although $\mathrm{K} 12$

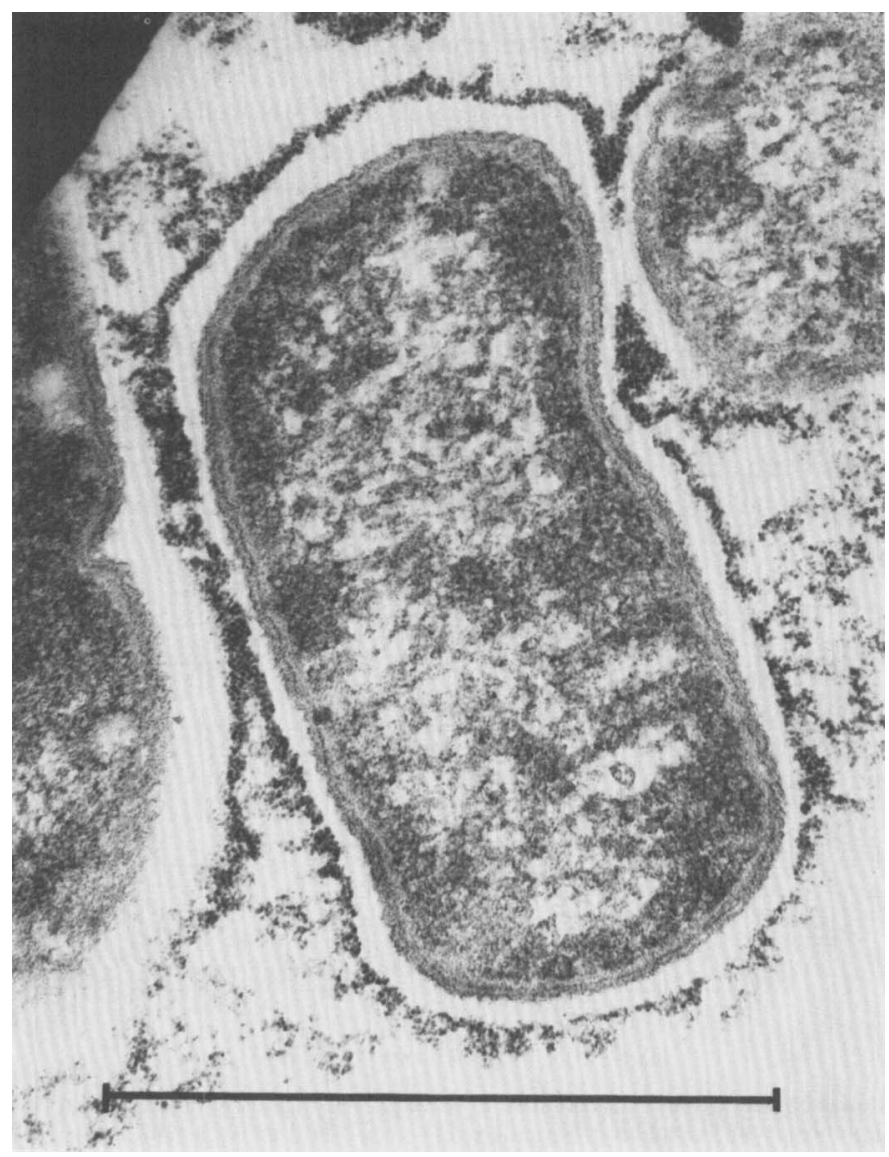

Fig. 2. Electron micrograph of cationic ferritin labelled E. coli strain A21 grown in mouse chambers. The bar marker represents $1 \mu \mathrm{m}$. 
strains failed to survive in rabbit chambers, isogenic strains harbouring ColV plasmids encoding either iron uptake systems or serum resistance determinants grew as well as the wild-type strains.

When chamber contents from mice and rabbits were examined by phase-contrast microscopy, the bacteria appeared morphologically similar to in vitro grown organisms. Individual cells were usually short rods exhibiting no signs of filamentation. The encapsulated strain A21 possessed an additional external layer which stained heavily with cationic ferritin (Fig. 2); in vivo and in vitro grown cells showed a similar degree of staining and both were agglutinated by antimeningococcal group B antiserum. No such additional layer was seen in either in vivo or in vitro grown cells of non-encapsulated strains. Thus the $\mathrm{K} 1$ capsular antigen was expressed in vivo in the chambers.

A feature of mouse or rabbit chambers harbouring Staphylococcus aureus is that they usually become encased in a mat of fibrous material (Day et al., 1980). The amount of material deposited around the implant varies according to the virulence of the strain, being more extensive with virulent organisms (Arbuthnott, 1981). Very little such material was observed surrounding chambers harbouring any of the E. coli strains studied, although large numbers of polymorphonuclear leucocytes were observed attached to the filters at the ends of the chambers.

\section{Susceptibility to the bactericidal activity of serum}

Escherichia coli strains differ in their sensitivity to the bactericidal activity of serum. Most serum resistance tests have previously been carried out using organisms harvested after growing with short generation times on rich medium in vitro. This is unlikely to resemble the conditions encountered during infection. Strains DU1000, B188, W3110(ColV, I-K94) and A21 harvested after growth in vitro in broth cultures or in vivo in mouse or rabbit chambers were tested for killing by NMS, NRS or NHS. Bacterial suspensions were mixed with undiluted serum as described in Methods and incubated statically at $37^{\circ} \mathrm{C}$ for up to $2 \mathrm{~h}$. The results obtained are presented in Table 2. Mouse serum was found to have a low bactericidal activity against all strains tested (results not shown). Strain DU1000 failed to grow efficiently in rabbit chambers and could not be tested against serum; however, after growth in vitro and in vivo in mouse chambers, it showed sensitivity to both NRS and NHS. Strain B188, on the other hand, showed a low sensitivity to both NRS and NHS after growth in vitro and in vivo in mouse chambers. W3110(ColV,I-K94) was more sensitive to NHS after growth in vitro and in rabbit chambers than to NRS under the same growth conditions. Increased sensitivity to NRS was shown when A21 was grown in mouse chambers, although rabbit grown organisms were more sensitive to NHS. Thus the pattern of sensitivity to serum is affected both by the source of the serum and the culture conditions of the bacteria.

Table 2. Resistance of in vivo and in vitro grown E. coli strains to killing by normal rabbit serum (NRS) and normal human serum (NHS)

Tests with in vitro grown organisms were repeated at least three times and tests with in vivo grown organisms were performed at least twice with different batches of organisms. In each case the extent of killing after $2 \mathrm{~h}$ incubation with serum at $37^{\circ} \mathrm{C}$ is designated as less than 10 -fold, 10-100-fold, or greater than 100 -fold reduction in viable count.

Extent of reduction in viable count after incubation with:

\begin{tabular}{lcccccc}
\multicolumn{4}{c}{ Strain } & $\overbrace{\text { In vitro }}$ Mouse grown & Rabbit grown & $\overbrace{\text { In vitro }}^{\text {NRS Mouse grown Rabbit grown }}$ \\
B188 & $<10$ & $<10$ & $<10$ & $<10$ & $<10$ & $>100$ \\
W3110 (ColV,I-K94) & $<10$ & $10-100$ & $<10$ & $>100$ & $<10$ & $>100$ \\
A21 & $<10$ & $>100$ & $<10$ & $<10$ & $<10$ & $>100$ \\
DU1000 & $>100$ & $>100$ & $*$ & $>100$ & $>100$ & $*$
\end{tabular}

* Strain DU1000 failed to grow in rabbit chambers. 
Polypeptide composition of the E. coli cell envelope after growth in vivo in rabbit chambers

Little is known about the composition of $E$. coli cell envelopes during periods of growth in vivo. The serum resistance tests described above indicated that in some cases in vivo grown organisms exhibited altered susceptibility towards serum when compared with in vitro grown organisms. Chamber supernatant fluids and washings from $E$. coli organisms grown in vivo in rabbit chambers were tested for the presence of rabbit serum proteins using swine anti-rabbit serum and swine anti-rabbit IgG antibodies. Rabbit serum proteins and IgG were readily detected in the chamber supernatant fluid using immunodiffusion tests. Small amounts of serum proteins, including IgG, could be eluted from in vivo grown cells by repeated washing in buffer. Double diffusion tests with concentrates from the second buffer wash are shown in Fig. 3(a,b). No host serum protein was detected in washings from in vivo grown organisms which had been centrifuged through $20 \%(\mathrm{w} / \mathrm{v})$ sucrose. Thus some serum protein may be non-specifically associated with the bacteria. However organisms of all E. coli strains grown in vivo, but not in vitro, which had been thoroughly washed were strongly agglutinated by swine anti-rabbit IgG antibody in slide agglutination tests, showing that rabbit immunoglobulins were tightly bound.

Cell envelopes were prepared from $E$. coli strains grown overnight in broth or for several days in rabbit chambers and their polypeptide composition was examined by SDS-PAGE. Results obtained with A21 and B188 are shown in Fig. 4. Although the system has limited resolving power, a number of differences were detected. Large amounts of a polypeptide of molecular mass $52000 \mathrm{Dal}$ (band A) were found associated with cell envelopes from all in vivo grown organisms. This polypeptide migrates on gels close to the heavy chain of IgG class immunoglobulins. Smaller amounts of three polypeptides of 57000, 24000, and $20000 \mathrm{Dal}$ (arrowed) were consistently detected in cell envelope preparations of in vivo grown organisms only. Careful examination of the stained polypeptides revealed a large number of other differences between the polypeptide patterns of in vivo and in vitro grown organisms. The major envelope polypeptides expressed by in vitro grown organisms could be detected in the envelopes of in vivo grown organisms. However there were differences, some quantitative, in the pattern of the minor envelope components. Differences in some bands were in some cases limited to individual E. coli strains. Further careful analysis is required to distinguish between tightly bound host polypeptides and altered membrane proteins (see Discussion).
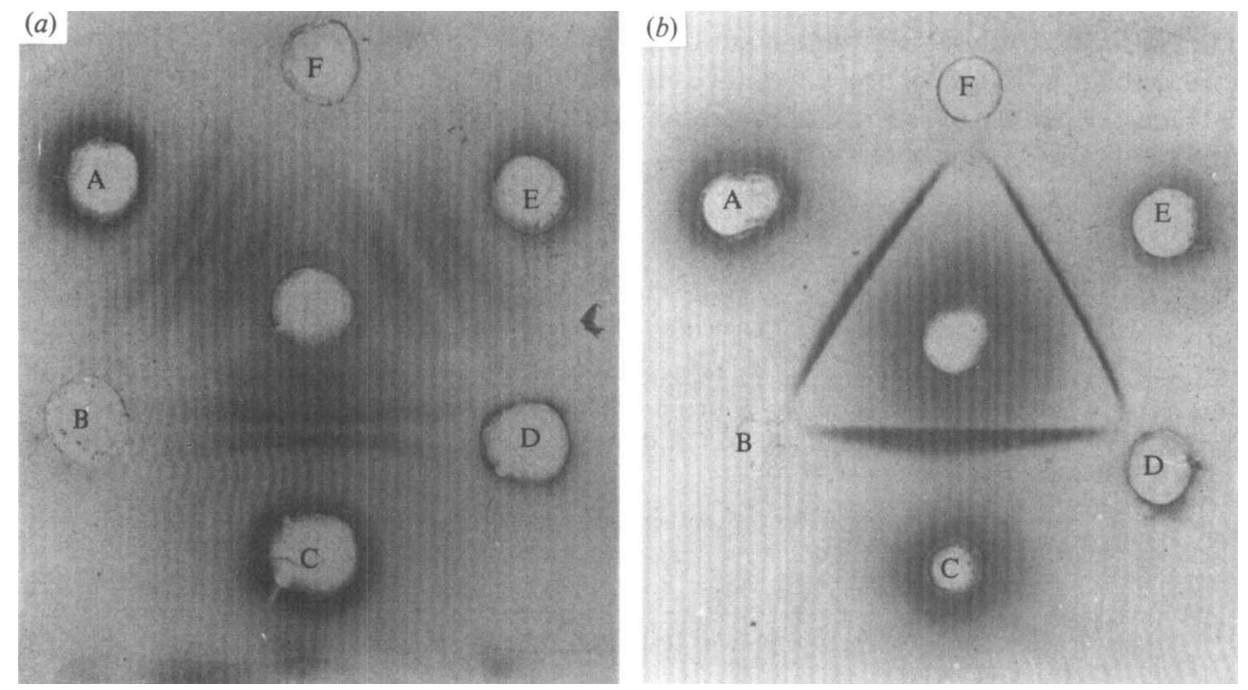

Fig. 3. Double diffusion gel of second buffer washes from in vivo grown organisms from rabbit chambers and in vitro grown organisms (see Methods) against swine anti-rabbit serum antibodies $(a)$ and swine anti-rabbit immunoglobulin antibodies $(b)$. In both gels the outside wells contain ammonium sulphate concentrated washes (dialysed against PBS) from: A, B188 in vivo; B, B188 in vitro; C, W31 10(ColV,I$\mathrm{K} 94)$ in vivo; D, W3110(ColV,I-K94) in vitro: $\mathrm{E}, \mathrm{A} 21$ in vivo; and $\mathrm{F}, \mathrm{A} 21$ in vitro. 


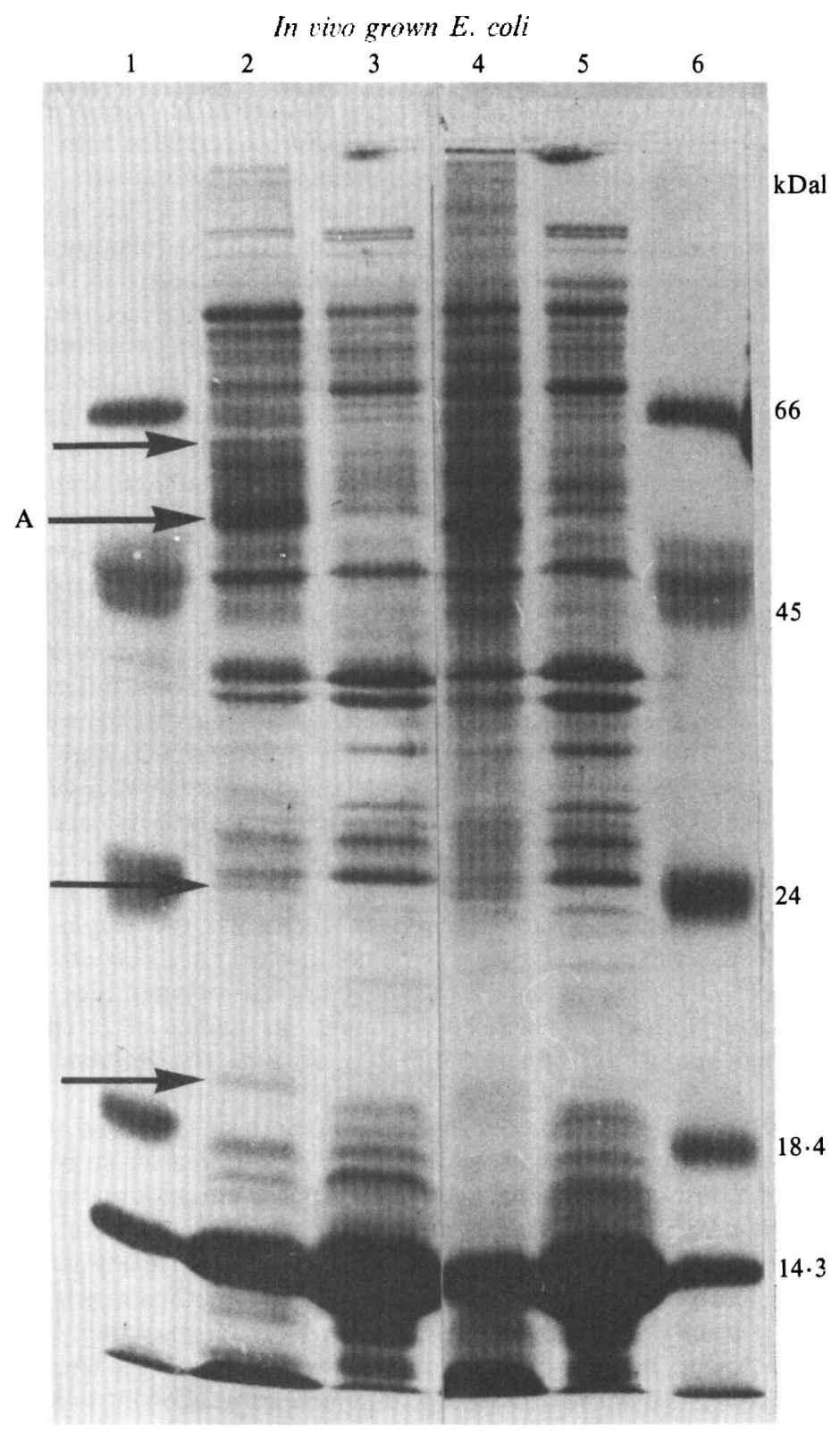

Fig. 4. Polypeptide pattern of cell envelope preparations electrophoresed on an SDS-polyacrylamide gel $(12.5 \%, \mathrm{w} / \mathrm{v})$ stained with Coomassie blue R250. Tracks 1 and 6 are the molecular mass standards: bovine serum albumin, 66000 ; ovalbumin, 45000 ; pepsin (porcine stomach mucosa), 34000; trypsinogen (bovine pancreas), 24000; $\beta$-lactoglobin (bovine milk), 18400 and lysozyme (egg white), 14300. Track 2, B188 grown in vivo in rabbit chambers; track 3, B188 grown in vitro; track 4, A21 grown in vivo in rabbit chambers; track $5, \mathrm{~A} 21$ grown in vitro. The arrows indicate the polypeptides present in the in vivo but not in the in vitro envelope preparations.

\section{DISCUSSION}

It is clear from previous studies that $E$. coli strains differ in their potential to invade tissue and cause infection. A number of virulence factors have been identified and in some cases they have been shown to play a role in vivo during the infection process (Smith \& Huggins, 1980). Little is known about how components of the host defence system and the surface structures of invasive 
micro-organisms interact at the molecular level or about the composition of organisms growing in vivo. This study shows that $E$. coli strains differ in their ability to grow in chambers implanted into the peritoneal cavities of animals. Further, organisms recovered from these chambers after periods of implantation differ structurally and physiologically from in vitro grown organisms. Laboratory $E$. coli $\mathrm{K} 12$ strains grew in mouse chambers but were killed in rabbit chambers, whereas isogenic strains harbouring ColV plasmids grew well. Acquisition of either ColV,IK94, encoding a serum resistance determinant, or ColV-H247 encoding an iron uptake system, enabled the $\mathrm{K} 12$ strains to grow in vivo and overcome the host defence mechanisms acting in the chamber. Strains B188 and A21, which were originally isolated from extra intestinal infections, both grew well and were apparently not killed efficiently in the chambers. Although in vivo grown A21 expressed high levels of capsular material, evidence from agglutination tests using anti-rabbit IgG antibodies showed that, in common with other in vivo grown $E$. coli, IgG was bound tightly to the cell envelope. Recently in vitro grown encapsulated Staphylococcus aureus have been shown to bind IgG (King \& Wilkinson, 1981). Interestingly, when phagocytic cells entered the chambers due to leakage or during sampling, the in vivo grown organisms were readily phagocytosed ( $\mathrm{T}$. Finn, unpublished observation). Thus, in vivo grown organisms may be useful in studying phagocytosis as they are already opsonized by host antibodies.

Analysis of the polypeptide composition of cell envelopes prepared from in vivo and in vitro grown organisms on SDS-PAGE revealed significant differences. These differences may be due in part to the binding of host serum components as well as to changes in the level of expression of bacterial polypeptides. The polypeptides of molecular masses 52000 and 24000 Dal could correspond to IgG heavy and light chain components bound to the $E$. coli envelopes. Indeed the 24000 but not the 52000 Dal polypeptide reacts with swine anti-rabbit IgG antibodies if washed SDS-polyacrylamide gels, similar to those shown in Fig. 4, are overlaid with agarose containing this antibody using a method described by Kehoe et al. (1981) (T. Finn, unpublished observation). Further experiments are required to determine the origin(s) of the 52000 polypeptide. Not all the differences in polypeptide composition are likely to be due to bound host material. Other variations in the levels of bacterial polypeptides probably reflect adaptation to the vastly different growth environment. In studies of $E$. coli pathogenicity, analysis of envelope composition should take into account the influence of the growth environment.

The differences observed in resistance to bactericidal activity of rabbit and human serum between in vivo and in vitro grown organisms were complex. Altered serum resistance could be due to the reaction of mouse or rabbit antibodies with exposed antigens on the surface of in vivo grown organisms, the expression of novel bacterial antigens in vivo, or a combination of these factors. The interaction between serum components and $E$. coli surface antigens is complex and poorly understood. Clearly care should be taken in designating strains resistant or sensitive to serum on the basis of results obtained with in vitro grown organisms alone. Demonstration of serum resistance in vitro does not prove a role for this in disease processes. Neisseria gonorrhoeae has previously been shown to have altered susceptibility to serum following in vivo growth. These organisms were also shown to express novel antigens in vivo (Penn et al., 1976).

In summary, it is clear that important differences exist in the properties of in vivo and in vitro grown $E$. coli. It is essential that all studies carried out on the pathogenic properties of in vitro grown $E$. coli are supported by evidence obtained from the in vivo situation. More studies are obviously required in this neglected area.

This work was supported by a Wellcome Trust grant to G. D. T.F. was supported by an Irish MRC studentship. Thanks go to L. Winston, D. A. John and the TCD electron microscopy unit for assistance, B. Gill and S. Day for help with operations, R. Russell for reading the manuscript, C. Harrison for typing it and other members of the microbiology department for media, equipment and ideas.

\section{REFERENCES}

ARbuthNotT, J. P. (1981). Membrane damaging toxins in relation to interference with host defence mechanisms. In The Beecham Colloquia. Microbial
Perturbation of Host Defences, p. 97. Edited by F. O'Grady \& H. Smith. London: Academic Press. ARKo, R. J. (1972). Neisseria gonorrhoeae: experi- 
mental infections of laboratory animals. Science $\mathbf{1 7 7}$, 1200-1201.

Binns, M. M., Davies, D. C. \& HaRdy, K. G. (1979). Cloned fragments of the plasmid ColV,I-K 94 specifying virulence and serum resistance. Nature, London 279, 778-781.

Day, S. E. J., VASLI, K. K., Russell, R. J. \& ARbUthNOTT, J. P. (1980). A simple method for the study of in vivo bacterial growth and accompanying host response. Journal of Infection 2, 39-51.

Dougan, G. \& SherratT, D. J. (1977). Transposon Tnl as a probe for the structure and function of plasmid ColE1. Molecular and General Genetics 151, 151-160.

Foster, T. J. \& Willetts, N. S. (1976). Genetic analysis of deletions of R 100-1 that are both transfer deficient and tetracycline sensitive. Journal of General Microbiology 93, 133-140.

Gladstone, G. P. \& Glencross, E. J. G. (1960). Growth and toxin production of staphylococci in sellophane sacs in vivo. British Journal of Experimental pathology 41, 313-333.

Houser, E. D. \& BERRY, L. J. (1961). The pathogenesis of staphylococcus infections. 1. The use of difffusion chambers in establishing the role of staphylococcus toxins. Journal of Infectious Diseases 109, 24.

Kehoe, M., Sellwood, R., Shipley, P. \& Dougan, G. (1981). Genetic analysis of K88-mediated adhesion of entero-toxigenic Escherichia coli. Nature, London 294, 122-126.

KING, B. \& WILKINSON, B. J. (1981). Binding of human immunoglobulin $\mathrm{G}$ to Protein A in encapsulated Staphylococcus aureus. Infection and Immunity 33, 666-672.

Moll, A., Manning, P. A. \& Timmis, K. N. (1980). Plasmid determined resistance to serum bactericidal activity: a major outer membrane protein, the traT gene product is responsible for plasmid specified serum resistance in $\boldsymbol{E}$. coli. Infection and Immunity $\mathbf{2 8 ,}$ 359-367.

Penn, C. W., Sen, D., Veale, D. R., Parsons, N. J.,
Smith, H. \& WITT, K. (1976). Morphological, biological and antigenic properties of $N$. gonorrhoeae adapted to growth in guinea pig subcutaneous chambers. Journal of General Microbiology 97, 35-43.

QUaKenBush, R. L. \& FalKow, S. (1979). Relationship between Colicin V activity and virulence in $E$. coli. Infection and Immunity 24, 562-564.

RoANTrEe, R. J. \& Collis, L. (1960). Effect of the peritoneal fluid of the guinea pig on strains of enteric bacilli. Nature, London 187, 1045-1046.

Robbins, J. B., McKracken, G. H., Gotschlich, E. C., Orskov, F., Orskov, I. \& Hansen, L. A. (1974). E. coli K l capsular polysaccharide associated with neonatal meningitis. New England Journal of Medicine 290, 1216-1221.

SMITH, H. (1977). Microbial surfaces in relation to pathogenicity. Bacteriological Reviews 41, 474-500.

Smith, H. Williams (1974). A search for transmissible pathogenic characters in invasive strains of $E$. coli: the discovery of a plasmid controlled toxin and a plasmid controlled lethal character closely associated, or identical with colicin V. Journal of General Microbiology 83, 95-111.

Smith, H. Williams \& Huggins, M. B. (1980). The association of the $\mathrm{O} 18, \mathrm{~K} 1$ and $\mathrm{H} 7$ antigens and the ColV plasmid of a strain of $E$. coli with its virulence and immunogenicity. Journal of General Microbio$\log y$ 121, 387-400.

Weiss, R., Schiefer, H. G. \& Krauss, H. (1979). Ultrastructural visualization of Klebsiella capsules by cationic ferritin. FEMS Microbiology Letters 6 , 435-437.

Williams, P. H. \& Warner, P. J. (1980). ColV plasmid-mediated, ColV independent iron uptake system of invasive strains of $E$. coli. Infection and Immunity 29, 411-416.

Witholt, B., BOCKHOUT, M., BROCK, M., KingMA, J., van Heerikhuizen, H. \& DE LeIJ, L. (1976). An efficient and reproducible procedure for the formation of spheroplasts for variously grown $E$. coli. Analytical Biochemistry 74, 160-170. 